\title{
Transport and health: a look at three Latin American cities
}

\author{
Transporte y salud: una mirada a tres ciudades \\ latinoamericanas
}

Transporte e saúde: um olhar sobre três cidades latino-americanas

\author{
Janeth Mosquera Becerra 1,2 \\ Rodrigo S. Reis 3 \\ Lawrence D. Frank 4 \\ Farah A. Ramirez-Marrero 5 \\ Benjamin Welle 6 \\ Eugenio Arriaga Cordero ${ }^{2}$ \\ Fabian Mendez Paz ${ }^{1}$ \\ Carlos Crespo 2 \\ Veronica Dujon 2 \\ Enrique Jacoby 7 \\ Jennifer Dill 2 \\ Lynn Weigand 2 \\ Carlos M. Padin 8
}

\section{Resumen}

El transporte está asociado con problemas ambientales, pérdidas económicas, salud poblacional e inequidades sociales. En ciudades de Europa y Estados Unidos hay iniciativas para promover el transporte multimodal. En Latinoamérica hay proyectos en curso para cambiar los sistemas de transporte y estimular el transporte no motorizado (caminar y montar bicicleta). Basada en una revisión de artículos publicados en revistas académicas, se identifica de qué forma los cambios en el transporte en Bogotá (Colombia), Curitiba (Brasil) y Santiago (Chile) han contribuido a promover el transporte activo. A pesar que en estas tres ciudades se están implementando iniciativas para promover el transporte activo (sistema de autobuses articulados, ciclovías, ciclorutas, y restricciones para el uso del coche particular), pocos estudios han sido desarrollados sobre la relación entre el transporte y la actividad física utilitaria. La tenencia del coche particular continúa incrementándose. El sector de salud necesita ser un agente fuerte para incorporar la salud pública en la agenda de transporte en América Latina.

Migración Pendular; Transportes; Ciclismo; Caminata 


\section{Background}

An intensive and rapid worldwide process of urbanization over the last two centuries meant that by $201050 \%$ of the world's population was already living in urban areas. Although rates differ across regions, the United Nations calculates that on average $74 \%$ of the population of developed countries and $43 \%$ of the population of less developed countries live in urban areas 1 . Transport is a key aspect of urban life due to its impact on economic growth, social interaction and urban structure 2 Although transport-related policies and projects are not, strictly speaking, health interventions, they have a potential impact on individual and collective health 3,4,5,6. Therefore, urban transport policies and projects need to be monitored and evaluated to identify their social, economic and environmental costs and to define strategies to improve the public health benefits of such interventions 7 .

Transport is associated with environmental problems, economic losses and social inequalities and is a social and physical determinant of health. Motor vehicles are one of the main sources of environmental pollution. They produce $26 \%$ of carbon dioxide $\left(\mathrm{CO}_{2}\right)$ emissions, one of the major causes of global warming 8 , which in turn is responsible for changes in worldwide distribution patterns of infectious diseases such as dengue fever and malaria ${ }^{9}$. In addition, the increased number of motor vehicles and associated increase in fuel consumption affects air, water and soil quality. Poor air quality is associated with respiratory disease 10,11 , cardiovascular morbidity, mortality 12 , premature deaths 13 and ocular irritation 14 , leading to an increase in the use of health services and out-of-pocket health care expenses 15. Policy decisions regarding urban mobility affect exposure to motorized transport related injury 16 because the risk of injury is directly associated with the number of vehicles on the roads 17,18. Furthermore, transport related injury is associated with mental health problems 19 and stress levels and mood are associated with commuter transportation choices 20 .

Transport is also related to other social determinants of health. Inadequate public transport infrastructure can exacerbate social segregation and restrict access to labor markets 21 . Furthermore, poor public transport can hinder access to educational institutions, health care services and cultural services 22. A study carried out in England for example reported that people without a car face greater difficulties in finding employment, accessing supermarkets and seeking medical attention 23 . As a result, poor transport infrastructure can accentuate social inequality. Poor transport facilities may have an impact on people's dietary patterns, particularly among minority and lower income groups that are more likely to face geographical barriers to accessing healthy food 24,25 .

In contrast, an affordable, efficient, multimodal (combining different means of transport), accessible and interconnected public transport system stimulates interaction among people as well as a sense of belonging 26 . Additionally, a well-designed transport system facilitates the mobility of elderly people and enhances their autonomy 27.

The relationship between transport and physical activity has been particularly well documented. Research has shown that transport infrastructure can have an effect on physical activity because transport systems can provide an incentive to use multimodal means of transport thus leading to an increase in the level of physical activity in urban areas. Public transport can also contribute to the practice of physical activity, because accessing transport services often requires walking 28,29. Evidence also shows that car use and car dependence is a risk factor for obesity because excess driving leads to an imbalance between energy consumption and energy expenditure 30 . In fact, transport-related physical activity is a protective factor for chronic diseases, stress and obesity 31,32 .

Although the links between transport and health have been part of the academic and political agendas of Europe 16,33, the USA 34 and Canada 35 for over two decades, the relationship between transport and health remains understudied in Latin America. There is limited literature available specifically on the influence of transport systems on physical activity (walking or cycling as a means of transport) in urban areas. A recent review of transport and its relation with physical activity (e.g. active commuting) by Bauman et al. 36 reported that there is practically no evidence for such an association. An increase in physical activity among the population of this region is crucial because between 30 and $69 \%$ of Latin Americans do not meet physical activity recommendations and between 50 and $60 \%$ of Latin American and Caribbean adults are overweight or obese 37 . Physical activity can help reduce the risk of cardiovascular diseases, the main cause of mortality $(31 \%)$ and premature death in this region. Furthermore, transportrelated physical activity is a practice that can be easily incorporated into people's daily lives.

This paper, based on articles from peerreviewed academic journals from the HINARI (Programa de Acceso a la Investigación en Salud), 
SciELO (Scientific Electronic Library Online) and LILACS (Literatura Latinoamericana y del Caribe en Ciencias de la Salud) databases, official reports, daily journals, and website pages, aims to analyze public transport initiatives and active modes of transport in three selected Latin American cities [Bogotá (Colombia), Santiago (Chile) and Curitiba (Brazil)] and their potential contribution to increasing physical activity (walking and cycling). The cities were selected because they all have large urban centers with high rates of urbanization (over 75\%). Furthermore, the transport systems and urban mobility in Curitiba and Bogotá have been subject to wide changes over the last decades and both cities have been indicated as successful examples of urban transport 38,39 .

Firstly, a search of the following four transport strategies, each with potential to promote physical activity (walking and cycling), was carried out using gray literature and non-indexed documents (Google search) to characterize the initiatives in each city: Bus Rapid Transit (BRT) systems, car use restriction measures, CicloviaRecreativa programs, and the construction of cycle paths. Subsequently, a search of academic papers exploring the relationship between these initiatives and physical activity (walking and cycling) written up to 2011 was undertaken using the HINARI, SciELO and LILACS databases. These databases were used because they provide academic literature produced mainly in Latin American countries. Furthermore, HINARI offers free access and it includes important sources of health literature such as PubMed/MEDLINE.

The following combinations of key words in three languages (Spanish, Portuguese and English) were used together with the names of each city (Curitiba, Bogotá and Santiago): "transportation AND physical activity”, "Bus Rapid Transi AND physical activity, "Ciclovias AND physical activity", "cycle paths or bike lane AND physical activity", "car free day AND physical activity" (i.e. transportation x physical activity x Curitiba). Only papers that explored the relationship between these initiatives and physical activity were selected for this review. In addition, two academic papers suggested by an expert were included in the study. The search was done between January 2011 and March 2011.

The peer-reviewed articles considered by this study are shown in Table 1.

\section{Transport and physical activity in Latin American cities}

Today, around $75 \%$ of the Latin American population lives in urban areas. The pace of urbanization is more rapid in Latin America than in North America and Europe 40 and the rate is expected to increase to $82 \%$ by 2025 . This process has contributed to a modified urban infrastructure in the region and, as a result of globalization, major cities have been important drivers of competitiveness (encouragement of international investment) since the 1980s 41 . Transport systems play an ever more important role in mobility and urban productivity and over the last 20 years a significant number of transport projects have been implemented in several Latin American cities.

One of the most important initiatives is the BRT system promoted by the World Bank 42 that has been offering loans aimed at implementing this system in cities around the world over the last three decades. BRT consists of a number of articulated buses each with capacity of more than 150 passengers that move along exclusive corridors using fixed stations to pick up and drop off passengers. BRT systems have been implemented in more than 70 cities worldwide, each with different characteristics with respect to infrastructure, costs, administration, speed, components, capacity and level of integration ${ }^{43}$. In Latin America, BRT systems have been implemented in Brazil (in Curitiba, Goiânia, Fortaleza, and Manaus), Ecuador (in Quito and Guayaquil), Peru (in Lima), Mexico (in Ciudad de México, Guadalajara and León), Colombia (in Cali, Pereira, Bogotá, Cartagena, Barranquilla, Medellín and Bucaramanga), where they are considered an efficient and cost-effective solution for urban mobility 44 .

Although the main objective of BRT is to increase urban mobility and reduce transport time, they also have the potential to stimulate the use of active modes of transport (cycling and walking) and reduce private car use, thus promoting physical activity ${ }^{34}$. The experience of implementing mass transportation systems such as BRT is a unique opportunity to evaluate the impact of transport on people's life in urban areas. However, evaluations using "natural" experiments with pre and post measures or prospective cohort studies remain scarce and to date only two studies are known to have evaluated the relationship between BRT and physical activity, both of which are cross-sectional studies: one carried out in Bogotá which is reviewed below 45; and a pre-post study underway (not yet published) in Cali, which evaluates the impact of a BRT system 
Table 1

Transport and physical activity (peer-reviewed articles included in this review).

\begin{tabular}{|c|c|c|c|}
\hline Papers & Focus & Main findings & City \\
\hline Reis et al. 61 & $\begin{array}{l}\text { Participation and knowledge on community } \\
\text { physical activity programs }\end{array}$ & $\begin{array}{l}\text { Public transportation provides access to facilities } \\
\text { where physical activity community programs are } \\
\text { delivered }\end{array}$ & Curitiba, Brazil \\
\hline Parra et al. 62 & $\begin{array}{l}\text { Self-perception of environmental attributes and } \\
\text { physical activity }\end{array}$ & $\begin{array}{c}\text { Meeting recommendations of physical activity } \\
\text { levels was associated with high perceptions of } \\
\text { infrastructure accessibility (i.e. built bicycling and } \\
\text { walking trails) }\end{array}$ & Curitiba, Brazil \\
\hline Hino et al. 22 & $\begin{array}{l}\text { Objective measures of the built environment and } \\
\text { recreational physical activity }\end{array}$ & $\begin{array}{l}\text { Density of bike paths was not associated with } \\
\text { physical activity in leisure time }\end{array}$ & Curitiba, Brazil \\
\hline Cervero et al. 69 & $\begin{array}{l}\text { Built environment and physical activity } \\
\text { (walking and bicycling) }\end{array}$ & $\begin{array}{l}\text { BRT stations (TransMilenio) were associated with } \\
\text { utilitarian walking. Living nearby to a to Ciclovía } \\
\text { increase Ciclovia usage. Density of bike paths was } \\
\text { not associated with utilitarian bicycling }\end{array}$ & Bogotá, Colombia \\
\hline Gomez et al. 45 & $\begin{array}{l}\text { Built environment and physical activity } \\
\text { in leisure time }\end{array}$ & $\begin{array}{l}\text { BRT stations (TransMilenio) were associated with } \\
\text { physical activity in leisure time. Existence of bike } \\
\text { lanes was not associated with physical activity in } \\
\text { leisure time }\end{array}$ & Bogotá, Colombia \\
\hline Gomez et al. 70 & Built environment and walking patterns & $\begin{array}{l}\text { Ciclovia was associated with walking at least } 150 \\
\text { minutes per week }\end{array}$ & Bogotá, Colombia \\
\hline Rodríguez et al. 71 & BRT stations (TransMilenio) and pedestrian activity & $\begin{array}{c}\text { Friendly pedestrian environment around or along } \\
\text { BRT stations (TransMilenio) incentive pedestrian } \\
\text { activity }\end{array}$ & Bogotá, Colombia \\
\hline Sarmiento et al. 58 & Ciclovía programs and physical activity & $\begin{array}{l}\text { Ciclovía program has contributed to increasing } \\
\text { levels of physical activity }\end{array}$ & Bogotá, Colombia \\
\hline
\end{tabular}

BRT: Bus Rapid Transit.

implemented in 2009 on physical activity and quality of life 46 .

Despite the health benefits of these systems implemented in Latin American cities, private car ownership in this region has been increasing steadily. Although rates do not yet match those of countries such as Luxembourg, which has the highest rate of car ownership in the world (647 cars per 1,000 population), New Zealand (607 cars per 1,000 population) 47 , or China, which became the world leader in domestic car sales in 2009 (13 million per year) ${ }^{48}$, private car ownership continues to rise in cities in Latin American countries such as Brazil, Argentina, Chile (97 per 1,000 population), Mexico (138 per 1,000 population) and Colombia (where car sales increased by approximately 50\% between 2004 and 2005) 49,50. A particularly striking case is Curitiba where, despite being a city with a public transport system that stands as an internationally recognized model, car ownership rates are one of the highest in Brazil 51. Studies show that in some European, Canadian, Australian and U.S. cities, increas- ing car ownership does not necessarily lead to an increase in car-usage 52 . However, in Latin American cities with lower use of non-motorized modes of transport, the higher social status offered by owning a car, irregular public transport systems and the trend of increasing car ownership is likely to have a negative impact on cycling and walking as means of transport.

A number of strategies aimed at restricting car use have been implemented to tackle the effects of traffic congestion on air quality. In 1989, for example, in Mexico City the program Hoy no Circula (No Circulation Today) was implemented which prohibited car owners and some public service vehicles (taxis and buses) from circulating between the hours of 5:00am and 10:00pm one day per week according to license plate number 53 . Similar programs have been implemented in other cities including São Paulo 54, Cali 55, Bogotá 56 and Santiago, where during rush hour or on certain days of the week drivers are prohibited from using their cars. Bike share programs, like the one implemented in Mexico City 57 , are also 
being offered as alternatives to motor vehicle use. However, these strategies have not contributed to a reduction in car ownership.

Initiatives to promote cycling as a means of transport and leisure-time are also being implemented in several Latin American cities as independent projects or together with BRT systems. One example is the Ciclovia-Recreativas program, an open community program developed principally in Latin American cities where main streets are closed off to motorized traffic during certain periods of the week to allow people to use these areas for cycling, walking, running or skating. Sarmiento 58 found that 38 of these initiatives have been implemented in 11 countries and that $80 \%$ of Ciclovias were connected with parks. These initiatives involved the closure of between one to $121 \mathrm{~km}$ of streets for between 18 and 64 days of the year. Pucher et al. 59 analyzed cycling infrastructure and highlighted a number of initiatives aimed at promoting cycling in Bogotá including the construction of separate bike paths connected with the public transport system, social and educational programs to encourage cycling and the definition of car-free areas.

In summary, four main transport strategies that have the potential to promote physical activity and improve people's health have been implemented recently in Latin American cities: BRT which has the potential to increase walking and cycling; car use restriction measures that promote the use of non-motorized means of transport; Ciclovias-Recreativas that promote physical activity on streets usually used by cars; and the construction of bike paths which allow cyclists and car drivers to share physical space and infrastructure. At the same time however, the number of privately-owned cars and motorcycles is also increasing in this region. The following section analyzes the experiences of successful initiatives to modify transport infrastructure in three Latin American cities to identify how these changes have influenced levels of physical activity and the main challenges facing these cities with respect to promoting transport-related physical activity. The socioeconomic characteristics of these cities are shown in Table 2.

Transport and health in Curitiba, Bogotá and Santiago

\section{Curitiba}

Curitiba is the capital city of the State of Paraná, located in the south of Brazil, and has 1,851,215 inhabitants. The city is home to the world's first BRT system, created in 1973 as part of the Ur- ban Master Plan designed in 1966. The system carries around 1.5 million passengers daily and is widely recognized as a successful transport model in terms of efficiency, quality, capacity and cost 60 .

While a direct evaluation of the relationship between BRT and physical activity in Curitiba is yet to be carried out, three studies exist that indirectly analyze the relation between Curitiba's urban planning process, transportation system and physical activity among the population. Reis et al. 61 found that $5.6 \%$ of Curitiba's adult population participates in physical activity programs promoted by the city government and highlight that the integration between public transportation and land-use regulation facilitates access to several recreational facilities which involve physical activity programs. Such programs are generally developed in public spaces, "including sports and leisure department units (that usually include a gymnasium, an exercise room and/or a pool), plazas, and cycling and walking paths" 61 (p. 138).

In a study of environmental perception and transport-related physical activity and physical activity during leisure time, Parra et al. 62 showed that $55 \%$ of the population of Curitiba reported walking and $8 \%$ reported cycling as a means of transport; interestingly, a perception of traffic safety, measured as "presence of traffic and drivers exceeding speed limits" 62 (p. 236), was not associated with walking or cycling. However, moderate and high levels of perception of personal security, evaluated as "perception of crime nearby and perceived safety when walking or cycling at night and during the day" 62 (p. 236), were associated with both walking and cycling. The authors argued that a feeling of personal safety is more relevant than the urban physical environment as a factor that influences physical activity behavior. Finally, Hino et al. 22 found that there was no association between living close to bike paths and levels of physical activity in parks and plazas during leisure time. However, this study showed an association between living in an area with a high density of gyms and recreational centers and meeting physical activity recommendations during leisure time.

In summary, although Curitiba is considered a model city in terms of its transport system, there is no current evidence that shows an association between the BRT system and increased levels of physical activity among the population. Furthermore, according to Parra et al. 62, apart from having a model BRT system, Curitiba has "the highest public transportation ridership in Brazil (85\%), the city also has the highest car/inhabitant ratio (1:2) in the country" 62 (p. 235). 
Table 2

Socio-economic characteristics of the selected cities.

\begin{tabular}{lccccc}
\hline City & Population * & $\begin{array}{c}\text { Density } \\
\text { (population/km²)** }\end{array}$ & GINI *** & $\begin{array}{c}\text { Human Development } \\
\text { Index } \\
\text { (by country-rank) \# }\end{array}$ & $\begin{array}{c}\% \text { urban } \\
\text { population \#\# }\end{array}$ \\
\hline Bogotá & $7,363,782$ & 15.058 & 0.61 & $0,71(87)$ & Colombia: 75.4 \\
Curitiba & $1,751,907$ & 4.568 & 0.59 & $0,71(84)$ & Brazil: 86.9 \\
Santiago & $4,668,473$ & 2.896 & 0.55 & $0,80(44)$ & Chile: 89.2 \\
\hline
\end{tabular}

Sources:

* Alcaldia Mayor de Bogotá D.C. 78; Instituto Brasileiro de Geografia e Estatística (IBGE) 79; and Instituto Nacional de

Estadística de Chile (INE) 80;

** Hidalgo \& Carrigan 43;

*** United Nations Human Settlements Program (UN-HABITAT) 81;

\# United Nations Development Program (UNDP) 82;

\#\# United Nations Department of Economic and Social Affairs (UN-DESA) 83.

Curitiba also has a network of more than $30 \mathrm{~km}$ of bike lanes shared mainly with pedestrian walkways. However, a study of the general use of this system and the relation between the increase in the size of the bike lane network and prevalence of cycling as a means of transport is yet to be carried out. Also, Ciclovias-Recreativas in Curitiba are not common 63 and no data is available regarding the effects of car use restriction and car-free days in Curitiba on prevalence of physical activity (walking or cycling).

\section{$\underline{\text { Bogotá }}$}

Bogotá is the capital of Colombia and has 7,363,782 inhabitants. The city has been undergoing an important process of urban change since 199064 and, as a result of a decentralization process that began in the mid-1980s, municipalities were granted new authority, including control over urban planning regulations. These changes included the implementation of a mass transport system based on the BRT system called TransMilenio which began operating in 2000 and is projected to cover $80 \%$ of the city by 2031 . Each articulated bus has the capacity to carry 160 passengers (48 seated and the rest standing). In addition, the city is developing initiatives to promote cycling and reduce private car use.

To complement the TransMilenio, the city is creating a network of bike-paths covering more than $330 \mathrm{~km}$ called Ciclorutas. This project encourages cycling as a means of transport to reduce air pollution, traffic congestion and automobile dependence. However, data reveals that, despite the significant investment in the development of the Ciclorutas network and the implementation of cycle-friendly policies, a small number of people regularly use a bicycle in Bogotá: in 1995, only $0.6 \%$ of the population used a bicycle on a regular basis and this percentage increased to $2 \%$ in 1999 and peaked at $4.4 \%$ in 200365 . Another study reported that only $3.3 \%$ of adults in Bogotá were sufficiently physically active through using a bicycle to meet health guidelines, and that $15.6 \%$ used a bicycle for at least 10 minutes a week 66 .

Bogotá is also experiencing a rapid increase in the number of motorcycles and private cars. Between 2004 and 2007, at least 74,108 new motorcycles were registered in the city and between 1995 and 2005 the number of cars per 1,000 inhabitants increased from 82.6 to 84.767 . This trend has a potentially negative impact on cycling and walking as means of transport and Parra et al. 68 has shown a positive association between car and motorcycle ownership and excess weight, obesity and abdominal obesity among men.

Like Curitiba, Bogotá is widely recognized for its transport system and changes in its urban environment and several studies have evaluated the relationship between its transport system and physical activity. Cervero et al. 69 found an association between distance from the mode of transport, measured as "the number of TransMilenio (BRT) stations", and utilitarian walking for 30 minutes or more per day. The authors also reported an association between proximity to a Ciclovia path and the use of the Ciclovia at least once a month. On the other hand, no association was found between utilitarian cycling and bikelane density; however, authors explain that this contradictory finding should be confirmed using a larger sample. Finally, these authors also 
reported that high volumes of traffic are an impediment to utilitarian cycling in Bogotá.

Gomez et al. 45 found that people who live in close proximity to a TransMilenio station are more likely to be irregularly active when compared with inactive people. The authors argue that urban changes related to pedestrian friendly initiatives together with the construction of the TransMilenio could explain why adult people living near TransMilenio stations are more physically active. However, the presence of bike lanes or Ciclovias was not associated with greater physical activity during leisure time. A study of the elderly by Gomez et al. 70 reported a slight association between the presence of Ciclovia-Recreativa and walking at least 150 minutes per week. Finally, Rodríguez et al. ${ }^{71}$ supported the hypothesis that the friendly pedestrian environment and crossing aids built around BRT stations in Bogotá encourage walking and promote BRT use.

The literature also shows that Bogotá is recognized for its successful experience with the implementation of $121 \mathrm{~km}$ of ciclovias-recreativas that are open every Sunday and on public holidays between the hours of 7 am and $2 \mathrm{pm}$, and were used by 1,400,273 people per month in 2005 , thus contributing to an increase in levels of physical activity 57 .

Car Free Days and car use restriction (known as "Pico y Placa" in Spanish) are other initiatives that stimulate the use of non-motorized transport in Bogotá; however, the impact of these initiatives on physical activity has yet to be reported.

\section{Santiago}

Santiago is the capital of Chile and has a population of 4,668,473 distributed throughout a metropolitan area consisting of 34 comunas. The city has a combined transport system that includes a metro (subway system) and BRT system called Transantiago which is connected by feeder buses and began operating in 2007 . Zegras 72 states that this system offers good quality buses, shorter routes, no competition between drivers to gain passengers, and uses an innovative card payment method which allows transfers without extra payment. The BRT system covers areas not served by the metro, aiming to reduce traffic congestion by discouraging private car use and encouraging the use of public transport. However, experts argue that the system has created other difficulties for citizens because it was implemented without initial testing.

Despite public efforts to increase ridership in Santiago, the number of private cars has increased sharply in recent years; between 1992 and 2002 car ownership increased from $24.3 \%$ to $36 \% 73$, the number of vehicles per household increased from 0.32 in 1977 to 0.5 in 2001 and cars journeys increased from $12 \%$ in 1977 to $39.6 \%$ in 2001 . Zegras 72 argues that having at least one vehicle per household is associated with increased family income. In a panel study carried out between December 2006 and October 2008, Yáñez et al. 74 analyzed the effects of the implementation of the Transantiago on different modes of travel. They reported an increment in the number of cars per household and argued that this increase may be the result of implementation problems. It is also interesting to note that $7 \%$ of individuals from the panel study bought a car and $2.3 \%$ acquired a driver's license for the first time after the system started operating. These findings illustrate the complexity of individual travel decisions and the importance of the quality of public transport systems. However, it is also necessary to consider the influence of changes in individual and family income on car ownership in Latin American cities. More research is necessary to determine the long-term effects of the Transantiago system on physical activity and health.

Other initiatives that aim to promote transport-related physical activity in Santiago are the CicloRecreoVia, a network of $7 \mathrm{~km}$ of bike/walking paths created in 2006 used by around 3,000 people per event 57 , and a program to restrict private car use during rush hours and periods of high air pollution implemented in 1980.

Studies on the relationship between changes in Santiago's transport system and levels of physical activity (walking and cycling) were not found in the literature.

Table 3 shows a comparison of transportation patterns in Curitiba, Bogotá and Santiago.

\section{Discussion}

Given the link between transport and health, it is imperative that individual and collective health issues are considered in designing urban transport policies and programs. Transport is a key social determinant of health, particularly in urban areas, which can help reduce social inequalities, improve people's mental and physical health, prevent injury and decrease environmental pollution 19. Findings from studies in Europe, Canada, Australia and the USA show that transport has a potentially positive effect on physical activity behavior 31 ; therefore, transport and health policies are indissociable. From the Latin American perspective, five main aspects of the relationship between transport and physical activity have been evaluated: (a) multimodal transport systems that incorporate 
Table 3

Urban transport patterns by city.

\begin{tabular}{lccccc}
\hline City & $\begin{array}{c}\text { Cycling for } \\
\text { transport (\%) }\end{array}$ & $\begin{array}{c}\text { Walking for } \\
\text { transport (\%) }\end{array}$ & $\begin{array}{c}\text { Cars per 1,000 } \\
\text { inhabitants (year) }\end{array}$ & $\begin{array}{c}\text { Motorcycles } \\
\text { per 1,000 } \\
\text { inhabitants }\end{array}$ & $\begin{array}{c}\text { BRT-total } \\
\text { passenger demand } \\
\text { (million), 2009 \# }\end{array}$ \\
\hline Bogotá * & 4.3 & 40.5 & $84.7(2005)$ & $\mathrm{NA}$ & 1.60 \\
Curitiba ** & 8.0 & 55.0 & $556.4(2010)$ & $75.6(2010)$ & 2.26 \\
Santiago *** & 1.9 & NA & $129.0(1998-2000)$ & $\mathrm{NA}$ & 5.70 \\
\hline
\end{tabular}

BRT: Bus Rapid Transit

Sources:

* Biking and walking for transport: Instituto Colombiano de Bienestar Familiar 49; Cars: Cámara de Comercio de Bogotá 67;

** Biking and walking for transportation: Parra et al. 62; Cars and motorcycles: Departamento de Trânsito do Paraná (Detran-

PR) 84 ;

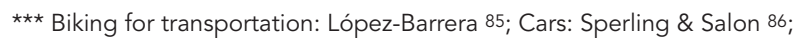

\# Hidalgo \& Carrigan 43.

walking and cycling; (b) the potential of BRT to promote walking/cycling to access the system; (c) public transport systems as a disincentive to private car use associated with reduced physical activity and increased sitting time; (d) significant modifications of transport systems involving urban changes (i.e. recuperation of public spaces, mixed use, micro-design and security) which potentially reduce the physical barriers to the use of non-motorized means of transport; and (e) measures and programs to discourage private car use and support active transport (i.e. "Pico y placa"). Despite the rich source of information for potential study provided by the experiences in these cities, the impressive changes in transport systems and the implementation measures to stimulate non-motorized means of transport, little research on the relationship between transport and physical activity and health has been carried out in Latin America to date. The main focus of study has been the implementation of BRT based mass transport systems. In this respect, a limited number of studies carried out in Bogotá showed a positive association between BRT and physical activity, one study in Curitiba showed an indirect relationship and one study in Santiago showed that household car use increased after the implementation of the BRT system. The three cities have Ciclorutas and BRT systems, but only in Bogotá were these two systems implemented in conjunction. While Dill \& Carr 75 report that physical infrastructure is an important factor per se that encourages bike use and bike commuting and studies of the Bogotá Ciclorutas found an association with physical activity during leisure time, no such association was found in the case of Curitiba. This suggests that physical infrastructure alone might not be enough to encourage cycling in Latin American cities.

This preliminary review highlights several factors that may explain the lack of evidence regarding transport and health in these cities. First, most evaluations of BRT systems have focused on performance related to cost, travel time reduction, comfort, capacity and design 76 because health was not considered as one of the main objectives of this system. This may reflect a possible lack of integration between the public health and urban planning sectors in the transport policy and program decision-making process. As a result, evidence on the impacts of BRT systems on people's health remains limited. Furthermore, differences in quality, design, costs and the implementation process potentially affect public acceptance and use of this mode of transport and may negatively impact its potential to encourage non-motorized means of transport. It is also necessary to investigate whether the BRT systems in these cities allow users to take bikes onto the buses and if the BRT system is integrated with the bike lane network. Answering these questions will help create a better understanding with respect to whether BRT prevents or encourages cycling (i.e. multimodal transport). In brief, in order to provide input into the policy decisionmaking process, more information is required on the impact of BRT and the cost-benefit of different policy scenarios that contemplate alternative urban transport strategies.

Second, urban physical infrastructure and people's behavior is a relatively new research area and technical and methodological developments are needed, such as updated geographical infor- 
mation systems. It is also important to create interdisciplinary teams and improve the availability of data from different sources, together with much needed financial resources which are limited in some Latin American cities. Research on transport and physical activity has been carried out largely in the USA and Europe. Studies in Latin America need take into account the specific characteristics of urbanization (land use and urban design) and motorization. Furthermore, in some cities car ownership has more social status than non-motorized means of transport (walking or cycling). Thus, while in the USA and Europe ample information exists on the factors that influence walking and cycling, in Latin America more research is necessary on the social and physical urban factors related to transport and physical activity.

Third, financial resource and time constraints are a limitation for studies on urban infrastructure and health. Cohort studies or "natural" experiments provide better scientific evidence but also require greater financial resources and support from research agencies. In this respect, local governments generally prefer to support short or medium-term research rather than long-term studies. Continued reviews of this nature are needed because transport affects many other health outcomes not included in this review such as, air quality, traffic injuries, social inequalities (i.e. access to goods, places and resources), social integration, and family spending on transport. For instance, Bogotá's experience in reducing traffic injuries deserves to be revisited 77 . It should also be emphasized that the role of the public health sector in the transport and urban land use sector is particularly important in Latin America due to the significant cross-cutting impacts on human health and well-being. From the social determinants of health perspective, public health researchers in Latin America should seek to influence the policy decisionmaking process to promote policies that positively impact active transport or non-motorized transportation; thus, contributing to an increase in levels of physical activity and a decrease in the risks of chronic diseases.

Finally, this narrative review has certain strengths and limitations. All academic papers published up to 2011 found in well recognized databases were included. A more comprehensive review was made possible by accessing wider sources of information by including additional databases (e.g. PubMed) and expanding each investigated topic as a separate item. Using other information sources and research techniques, such as interviews with key actors, could have contributed to elucidate why health (i.e. physical activity) has played such a limited role in public transport decision-making in the three cities.

\section{Resumo}

O transporte está associado a problemas ambientais, perdas econômicas, de saúde da população e as desigualdades sociais. Em cidades da Europa e da América existem esforços para promover o transporte multimodal. Na América Latina, há projetos em andamento para mudar os sistemas de transporte e incentivar o transporte não motorizado (caminhar e andar de bicicleta). Com base em uma revisão de artigos publicados em revistas acadêmicas identificou-se como as mudanças no transporte contribuíram para promover o transporte ativo em Bogotá (Colômbia), Curitiba (Brasil) e Santia- go (Chile). Apesar de que nestas três cidades se estejam implementando iniciativas para promover o transporte ativo (sistema de ônibus articulado, ciclovias, pistas de ciclismo e restrições ao uso do automóvel particular), poucos estudos têm sido desenvolvidos sobre a relação entre transporte e atividade física utilitária. $O$ uso de carro particular continua aumentando. O setor da saúde tem de ser um ativista forte para incorporar a saúde pública na agenda de transportes na América Latina.

Migração Pendular; Transportes; Ciclismo; Caminhada 


\section{Contributors}

J. M. Becerra participated in study conception, data collection and analysis, elaboration of the first draft and review of successive drafts, and the approval of the final version of this article. C. M. Padin, L. Weigand, J. Dill, V. Dujon, C. Crespo, F. M. Paz, E. A. Cordero, B. Welle, F. A. Ramirez-Marrero, L. D. Frank, R. S. Reis, and E. Jacoby participated in data collection and data analysis, critical review of the content of successive drafts and in the approval of the final version of this article.

\section{Acknowledgments}

The authors would like to thank Helen Paz from Portland State University for her valuable contribution in checking the English grammar of this paper.

The Consortium of Universities and Institutions on Transport and Health, as part of the WHO-Collaborative Center in Urban Sustainability field of Portland State University, aims to develop initiatives in research, training and interventions to improve health conditions in urban areas in Latin America, taking into account the relationship between transport and health in urban settings.

\section{References}

1. Department of Economic and Social Affairs, Population Division, United Nations. World urbanization prospects: the 2005 revision. New York: United Nations; 2006.

2. Small K. Urban transportation policy. In: Inman RP, editor. Making cities work: prospects and policies for urban America. Princeton: Princeton University Press; 2009. p. 63-93.

3. McCarthy M. Transport and health. In: Marmot M, Wilkinson R, editors. Social determinants of health. Oxford: Oxford University Press; 2005. p. 132-54.

4. Ogilvie D, Mitchell R, Mutrie N, Petticrew M, Platt S. Evaluating health effects of transport interventions. Am J Prev Med 2006; 31:118-26.

5. Dora C. A different route to health: implications of transport policies. BMJ 1999; 318:1686-9.

6. Tapia Granados JA. La reducción del tráfico de automóviles: una política urgente de promoción de la salud. Rev Panam Salud Pública 1998; 3:137-51.

7. World Health Organization. Health effects and risks of transport systems: the HEARTS project. http://www.euro.who.int/document/E88772.pdf (accessed on Feb/2011).
8. Chapman L. Transport and climate change: a review. Journal of Transport Geography 2007; 15:354-67.

9. Khasnis A, Nettleman M. Global warming and infectious disease. Arch Med Res 2005; 36:689-96.

10. Künzli N, Kaiser R, Medina S, Studnicka M, Chanel $\mathrm{O}$, Filliger P, et al. Public-health impact of outdoor and traffic-related air pollution: a European assessment. Lancet 2000; 356:795-801.

11. Friedman MS. Impact of changes in transportation and commuting behaviors during the 1996 Summer Olympic Games in Atlanta on air quality and childhood asthma. JAMA 2001; 285:897-905.

12. Finkelstein MM, Jerrett M, Sears MR. Traffic air pollution and mortality rate advancement periods. Am J Epidemiol 2004; 160:173-7.

13. Bell J, Cohen L. Health effects of transportation policy. In: Malekafzali S, editor. Healthy, equitable, transportation policy: recommendations and research. Oakland: Policy Link, The Convergence Partnership; 2010. p. 21-6. 
14. Saxena R, Srivastava S, Trivedi D, Anand E, Joshi S Gupta SK. Impact of environmental pollution on the eye. Acta Ophthalmol Scand 2003; 81:491-4.

15. Duki MIZ, Sudarmadi S, Suzuki S, Kawada T, TriTugaswatl A. Effect of air pollution on respiratory health in Indonesia and its economic cost. Arch Environ Health 2003; 58:135-43.

16. Organización Mundial de la Salud. Informe mundial sobre prevención de los traumatismos causados por el tránsito. http://whqlibdoc.who. int/paho/2004/927531599X.pdf (accessed on Jan/2009).

17. Dora C, Phillips M. Transport, environment and health. Copenhagen: World Health Organization Regional Office for Europe; 2000. (WHO Regional Publications, European Series, 89).

18. Peden MM. World report on road traffic injury prevention. Geneva: World Health Organization; 2004.

19. Davis A, Cavill N, Rutter H, Crombie H. Making the case: improving health through transport. London: Health Development Agency; 2005.

20. Wener RE, Evans GW. Comparing stress of car and train commuters. Transp Res Part F Traffic Psychol Behav 2011; 14:111-6.

21. Kawabata M, Shen Q. Job accessibility as an indicator of auto-oriented urban structure: a comparison of Boston and Los Angeles with Tokyo. Environ Plann B Plann Des 2006; 33:115-30.

22. Hino A, Reis R, Sarmiento OL, Parra D, Brownson R. The built environment and recreational physical activity among adults in Curitiba, Brazil. Prev Med 2011; 52:419-22.

23. Social Exclusion Unit, Office of the Deputy Prime Minister. Making the connections: final report on transport and social exclusion. London: Office of the Deputy Primer Minister; 2003.

24. Zenk SN, Schulz AJ, Israel BA, James SA, Bao S, Wilson ML. Neighborhood racial composition, neighborhood poverty, and the spatial accessibility of supermarkets in Metropolitan Detroit. Am J Public Health 2005; 95:660-7.

25. Burns CM, Inglis AD. Measuring food access in Melbourne: access to healthy and fast foods by car, bus and foot in an urban municipality in Melbourne. Health Place 2007; 13:877-85.

26. Douglas GCC. Rail transit identification and neigh bourhood identity. Exploring the potential for 'community-supportive transit'. Journal of Urban Design 2010; 15:175-93.

27. Metz D. Transport policy for an ageing population Transport Reviews 2003; 23:375-86.

28. Edwards RD. Public transit, obesity, and medica costs: assessing the magnitudes. Prev Med 2008; 46:14-21.

29. Besser LM, Dannenberg AL. Walking to public transit: steps to help meet physical activity recom mendations. Am J Prev Med 2005; 29:273-80.

30. Pendola R, Gen S. BMI, auto use, and the urban environment in San Francisco. Health Place 2007; 13:551-6.

31. Bassett Jr. DR, Thompson DL, Pucher J, Buehler R, Crouter SE. Walking, cycling, and obesity rates in Europe, North America and Australia. J Phys Act Health 2008; 5:795-814.
32. Hamer M, Chida Y. Active commuting and cardiovascular risk: a meta-analytic review. Prev Med 2008; 46:9-13.

33. Dora C. The world health report 2003 - shaping the future. http://www.who.int/whr/2003/chapter6/ en/index.html (accessed on 26/Jul/2012).

34. Sallis JF, Frank LD, Saelens BE, Kraft MK. Active transportation and physical activity: opportunities for collaboration on transportation and public health research. Transportation Research. Part A, Policy and Practice 2004; 38:249-68.

35. King N, Drouin L, Morency P. Urban transportation, a question of health. 2006 annual report on the health of the population. Montréal: Agence de la Santé et des Services Sociaux de Montréal, Direction de Santé Publique; 2006.

36. Bauman AE, Reis RS, Sallis JF, Wells JC, Loos RJF, Martin BW, et al. Correlates of physical activity why are some people physically active and others not? Lancet 2012; 380:258-71.

37. Organización Panamericana de la Salud. Estrategia mundial sobre alimentación saludable, actividad física y salud (DPAS). Plan de implementación en América Latina y el Caribe 2006-2007. Washington DC: Organización Panamericana de la Salud; 2006.

38. Jacoby E, Pardo CF. Ciudades del automóvil, obesidad y cambio climático: se alinean las crisis y también las soluciones. Bogotá: Slow Research; 2010

39. Wright L, Fulton L. Climate change mitigation and transport in developing nations. Transport Reviews 2005; 25:691-717.

40. Cerruti M, Bertoncello R. Urbanization and in ternal migration patterns in Latin America. In: Conference on African Migration and Urbanization in Comparative Perspective. Johannesburg; 2003. http://pum.princeton.edu/pumconference/ papers/1-Cerrutti.pdf.

41. Banco Mundial. Ciudades en movimiento. Revisión de la estrategia de transporte urbano del Banco Mundial. Washington DC: Banco Mundial; 2002.

42. World Bank. Transport business strategy. Safe, clean, and affordable. Transport for development. Washington DC: World Bank; 2007.

43. Hidalgo D, Carrigan A. Modernizing public transportation. Lessons learned from major bus improvements in Latin America and Asia. Washington DC: EMBARQ; 2011.

44. Wright L. Bus rapid transit. Sustainable transport: a sourcebook for policy-makers in developing cities. Eschborn: Deutsche Gesellschaft für Technische Zusammenarbeit; 2002.

45. Gomez LF, Sarmiento OL, Parra DC, Schmid TL, Pratt M, Jacoby E, et al. Characteristics of the built environment associated with leisure-time physical activity among adults in Bogotá, Colombia: a multilevel study. J Phys Act Health 2010; 7:196-203.

46. Secretaría de Salud Pública Municipal de Cali; Fundación FES-Social; Organización Panamericana de la Salud. Impacto de la implementación del Sistema de Transporte Masivo en la actividad física y la calidad de vida relacionada con salud de los residentes de la ciudad de Cali, Colombia. Cali: Secretaría de Salud Pública Municipal de Cali; 2008. 
47. Pocket world in figures. Highest car ownership. The Economist 2008; http://www.economist.com/ node/11318873 (accessed on 15/Jan/2013).

48. Greene DL, Plotkin SE. Reducing greenhouse gas emission from U.S. transportation. Arlington: Pew Center on Global Climate Change; 2011.

49. Instituto Colombiano de Bienestar Familiar. Encuesta Nacional de la Situación Nutricional en Colombia Bogotá, Colombia 2010. http://www. icbf.gov.co/icbf/directorio/portel/libreria/pdf/ 1ENSINLIBROCOMPLETO.pdf (accessed on 28/ Jul/2011).

50. Roberts I, Wentz R, Edwards P. Car manufacturers and global road safety: a word frequency analysis of road safety documents. Injury Prevention 2006; $12: 320-2$.

51. Thomson I. Impacto de las tendencias sociales, económicas y tecnológicas sobre el transporte público: una investigación preliminar en ciudades de América Latina. Santiago: Comisión Económica para América Latina y el Caribe; 2002.

52. Newman P, Kenworthy J. "Peak Car Use": understanding the demise of automobile dependence. World Transport Policy and Practice 2011; 17.2: 31-42.

53. Escamilla-Báez FP, Salazar-Monroy JH. Programa de restricción vehicular "Hoy No Circula" y similares en el mundo. Sus alcances y limitaciones. http://portal2.edomex.gob.mx/sma/cuida_ medioambiente/publicaciones_sma/documen tos_tecnicos/groups/public/documents/edomex_ archivo/sma_pdf_prog_rest_vehi_hoynoci.pdf (accessed on 06/Jan/2012).

54. São Paulo. Lei no 12.490, de 3 de outubro de 1997. Diário Oficial do Município de São Paulo 1997; 4 out.

55. Salcedo CA. Decreto no 0722. Por medio del cual se toman medidas para el mejor ordenamiento del transito de vehículos en las vías publicas del municipio de Santiago de Cali. Santiago de Cali: Municipio de Santiago de Cali; 2005.

56. Peñalosa E. Decreto no 626 de 1998. Ordenamiento del tránsito de vehículos en las vías públicas de Santa Fe de Bogotá, D.C. Santa Fe de Bogotá: Alcaldía Mayor de Bogotá; 1998.

57. Shaheen S, Guzman S, Zhang H. Bikesharing in Europe, the Americas, and Asia: past, present, and future. http://www.escholarship.org/uc/ item/79v822k5 (accessed on 06/Jan/2012).

58. Sarmiento OL, Torres A, Jacoby E, Pratt M, Schmid TL, Stierling G. La ciclovía-recreativa: un programa masivo de recreación con potencial en salud pública. J Phys Act Health 2010; 7 Suppl 2:S163-80.

59. Pucher J, Dill J, Handy S. Infrastructure, programs, and policies to increase bicycling: an international review. Prev Med 2010; 50:S106-25.

60. Rogat J, Hinostroza M, Ernest K. Sustainable transport practices in Latin America through mass transit technologies. In: École Nationale Polytechnique, editor. Actes. Colloque International Environnement et Transports dans des Contextes Différents. Ghardaia: École Nationale Polytechnique; 2009. p. 83-92.
61. Reis RS, Hallal PC, Parra DC, Ribeiro IC, Brown son RC, Pratt M, et al. Promoting physical activity through community-wide policies and planning: findings from Curitiba, Brazil. J Phys Act Health 2010; 7:137-45

62. Parra DC, Hoehner CM, Hallal PC, Ribeiro IC, Reis $\mathrm{R}$, Brownson RC, et al. Perceived environmental correlates of physical activity for leisure and transportation in Curitiba, Brazil. Prev Med 2011; 52:234-8.

63. Bicicletada Curitiba. A rua é de todos! http://bi cicletadacuritiba.wordpress.com/ (accessed on Feb/2011).

64. Parra D, Gomez L, Pratt M, Sarmiento O, Mosquera J, Triche E. Policy and built environment changes in Bogotá and their importance in health promotion. Indoor Built Environment 2007; 16:344-8.

65. Suero D. La bicicleta como medio de transporte en la ciudad de Bogotá, 2007. http://hdl.handle. net/1992/849 (accessed on 23/Jul/2011).

66. Gomez LF, Instituto Distrital de Recreación y Deporte. Estudio para determinar los niveles de actividad física en las personas de 18 a 65 años de la ciudad de Bogotá. Bogotá: Fundación FES SocialInstituto Distrital de Recreación y Deporte; 2003.

67. Cámara de Comercio de Bogotá. Caracterización e indicadores de la movilidad en Bogotá. Observatorio de Movilidad de Bogotá y la Región; 2007. http://camara.ccb.org.co/documentos/11504_ob servatoriolmov.pdf (accessed on 15/Jan/2013).

68. Parra DC, Lobelo F, Gomez LF, Rutt C, Schmid T, Brownson RC, et al. Household motor vehicle use and weight status among Colombian adults: are we driving our way towards obesity? Prev Med 2009; 49:179-83.

69. Cervero R, Sarmiento O, Jacoby E, Gomez LF, Neiman A. Influences of built environments on walking and cycling: lessons from Bogotá. International Journal of Sustainable Transportation 2009; 3:203-26.

70. Gomez LF, Parra DC, Buchner D, Brownson RC, Sarmiento OL, Pinzon JD, et al. Built environment attributes and walking patterns among the elderly population in Bogotá. Am J Prev Med 2010; 38:592-9.

71. Rodríguez DA, Brisson EM, Estupinan N. The relationship between segment-level built environment attributes and pedestrian activity around Bogotá's BRT stations. Transportation Research. Part D, Transport and Environment 2009; 14:470-8.

72. Zegras C. The built environment and motor vehicle ownership and use: evidence from Santiago de Chile. Urban Studies 2010; 47:1793-817.

73. Ureta S. To move or not to move? Social exclusion, accessibility and daily mobility among the lowincome population in Santiago, Chile. Mobilities 2008; 3:269-89.

74. Yáñez MF, Mansilla P, de Dios Ortuzar J. The Santiago panel: measuring the effects of implementing Transantiago. Transportation 2010; 37:125-49. 
75. Dill J, Carr T. Bicycle commuting and facilities in Major U.S. cities: if you build them, commuters will use them. Transportation Research Record 2003; 1828:116-23.

76. Deng T, Nelson J. Recent developments in bus rapid transit: a review of the literature. Transport Reviews 2011; 31:69-96.

77. Cohen J. Calming traffic on Bogotá's killing streets. Science 2008; 319:742-3.

78. Departamento Administrativo Nacional de Estadísticas, Alcaldia Mayor de Bogotá D.C. Boletín Censo General 2005, perfil Bogotá. http://www. dane.gov.co/files/censo2005/PERFIL_PDF_ CG2005/11001T7T000.PDF (accessed on 24/Jan/ 2013).

79. Instituto Brasileiro de Geografia e Estatística. Cidades@, Paraná. http://www.ibge.gov.br/cidade sat/link.php?uf=pr (accessed on 24/Jan/2013)

80. Instituto Nacional de Estadística de Chile. Resultados generales censo, 2010. Santiago: Instituto Nacional de Estadística de Chile; 2010.

81. United Nations Human Settlements Programme. State of the world's cities 2010/2011 - cities for all: bridging the urban divide. Overview and key findings. Nairobi: United Nations Human Settlements Programme; 2010

82. United Nations Development Programme. Regional and national trends in the Human Development Index 1980-2011. http://hdr.undp.org/en/data/ trends/ (accessed on 24/Jan/2013).
83. United Nations Department of Economic and So cial Affairs. Urban population, development and the environment, 2011. http://www.un.org/esa/ population/publications/2011UrbanPopDevEnv_ Chart/urbanwallchart_2011-web-smaller.pdf (accessed on 24/Jan/2013).

84. Departamento de Transito do Paraná. Anuário estatístico de trânsito - 2010. http:/ / www.detran.pr.gov br/arquivos/File/estatisticasdetransito/anuario/ anuario2010.pdf (accessed on 22/Ago/2011).

85. López-Barrera R. Santiago pedaleará mucho más gracias a la construcción de ciclovías y estaciona mientos. Furiosos Ciclistas; 2008. http://www.fu riosos.cl/2008/02/10/santiago-pedaleara-muchomas-gracias-a-la-construccion-de-ciclovias-y-es tacionamientos-2/ (accessed on 23/Feb/2008).

86. Sperling D, Salon D. Transportation in developing countries: an overview of greenhouse gas reduction strategies. The Pew Center on Global Climate Change; 2002. http://www.c2es.org/docUploads/ transportation_overview.pdf (accessed on $01 /$ Nov/2012).

Submitted on 10/May/2012

Final version resubmitted on 23/Nov/2012

Approved on 03/Dec/2012 